\begin{tabular}{||r|c|c||}
\hline Received: July 2019 & Accepted: September 2019 & Published: October 2019 \\
\hline \hline Article DOI: http://dx.doi.org/10.24903/sj.v4i2.322 \\
\hline
\end{tabular}

\title{
Polysemy and Metaphorical Extensions of Temperature Terms: Warm and Cool
}

\author{
Truly Almendo Pasaribu \\ Universitas Sanata Dharma, Indonesia \\ trulyalmendo@usd.ac.id
}

\begin{abstract}
This study aims at finding out the prototypical meaning, the extended senses, and the relation between the prototypical meaning and the extended senses of these lexemes. This study uses a qualitative descriptive method that focuses on the classifications of the use of these words. Using cognitive-linguistic frameworks, this study discusses the three extended senses of the word warm, namely: (1) friendly, (2) pleasant to other senses, and (3) near the goal of the game. Furthermore, the word cool whose prototypical meaning is "having a low temperature" has four senses, namely: (1) calm, (2) unfriendly, (3) fashionable and (4) agreeable. These words which are originally expressed to describe the degree of heat are extended to describe other human physical experiences. The extension of those senses is motivated by metaphors as the temperature domain is pervasive to express non-temperature entity. The discussion highlights the relations between the central sense and the extended ones. The relation of the senses enables us to draw the semantic networks of polysemy warm and cool.
\end{abstract}

Keywords: polysemy; semantic network; extended senses

\section{INTRODUCTION}

Language constantly grows to meet basic human needs to communicate. One dynamic element of language is meaning. Words can shrink, but words can also take new meaning or extend new senses (Finegan, Besnier, Blair, \& Collins, 1992; (Areshenkoff, Bub, \& Masson, 2017; Course, 2018; Srinivasan, Al-Mughairy, Foushee, \& Barner, 2017). Some words called neologisms are created to carry novel concepts, while other words extend their senses or the 
domain of the reference. Take the word cut which has a different meaning in different constructions, such as: cut my finger, cut a deal, cut corners, and shortcut (Pasaribu, 2013). The senses of the word cut in each construction are extended. This linguistic phenomenon is called polysemy (Falkum \& Vicente, 2015.; Ibarretxe-Antuñano, 1999), the association of words which have two or more related sense.

Sizable research of words has focused on the forms, the meaning, and the functions in the sentences (Ahmad, 2000; Shalihah, 2015; Wijana, 2012). Shalihah (2015) analyses the components of words and the relationship among words in similar domains. Research on polysemy has been conducted by Wijaya (2011) to complete his thesis entitled "Polisemi pada Leksem head: Tinjauan Linguistik Kognitif". This research is conducted to analyze the polysemy of lexeme head. He found that there are 13 types of various senses of the lexeme head. Pasaribu (2013) also discusses the polysemy of the verb cut which can be found in different grammatical constructions. However, the study of the temperature terms mostly focus on the word hot. Therefore, it is crucial to analyze other words in temperature domain.

Context and metaphors should be taken into account when analyzing polysemy. Context has a very crucial role in triggering polysemy. Because meanings are related to context, certain contexts can provoke certain meaning. Evans \& Green (2006) states that "the reality is that some word senses while appearing to be distinct in certain contexts, appear not to be in others". In other words, polysemy is often a matter of degree and exhibits grade ability due to contextual influence. (Cruse, 2000; (Maine \& Hofmann, 2016; Yin, 2016) also identifies how context influences meanings of a single word, the context are situational context, sentential context, and knowledge context. The data of this current study solely focuses on sentential context. A polysemous lexeme has multiple, related meanings that have all been conventionalized to some degree. Among these related senses, some are more central, or prototypical or literal, than others, and some are schemas that are elaborated or instantiated by others. To some extent the senses are linked by categorizing relationships to form a network (Langacker, 2008; Stasiūnaitè, 2018).

This network can be analyzed because the extended senses of words tend to be motivated by metaphors (Arcimavičienè, 2011; Inčiuraitè, 2013; Linkevičiūtè, 2013). Cognitive linguists construct an argument that metaphor is naturally a cognitive process (Deignan, 2006; Moreno, 2005; Šeškauskienė \& Levandauskaitè, 2013; Velykoroda, 2019), which is a fundamental aspect of a language. In other words, it is not merely an ornament, but an aspect of mind and language (Lakoff \& Johnson, 2003). Metaphors manifest in words 
which are compared with other words (Hayani, 2016). Metaphors are a comparison between two different things that possibly share similar componential features. By paying close attention to context and metaphors, this study analyses the extended senses and the network of the temperature term warm and cool.

\section{METHODOLOGY}

This study used a qualitative-descriptive method that focuses on the description of the current language phenomenon. The method was carried out by gathering the data, analyzing the data and presenting the data. The corpus < http://www.natcorp.ox.ac.uk/ > gave natural and concrete data, while Oxford Learners' Dictionary and Cambridge Advanced Learner's Dictionary gave easiness to gather data which is not found in the corpus. The concepts in cognitive-linguistic such as metaphor, context, and semantic network were used to describe the form, meaning, and the relatedness between the senses. The data were taken from the corpus < http://www.natcorp.ox.ac.uk/ > by inserting the words, warm and cool. After data collection, the data were analyzed through several steps. First, the senses of the words are analyzed from a cognitive linguistic framework. This study determined the prototypical meaning of the words in the domain of temperature using the criteria suggested by Tyler and Evans (2001). The extended senses of the words in the domain of temperature were analyzed using Conceptual Metaphor Theory. Finally, this study analyzed how the relatedness of the prototypical meaning and the extended senses reflected in the Semantic Network.

\section{FINDINGS AND DISCUSSION}

Through a cognitive linguistic framework, the data consisting of the temperature words warm and cool are elaborated. The findings show the prototypical sense and the extended senses of these words. Furthermore, the discussion elaborates on how these senses are related through metaphors.

\section{Findings}

The prototype and extended senses of warm

The prototype meaning is the central meaning of the words. Tyler and Evans (2001) suggested four criteria in elaborating the core meaning. The first one is the earliest attested meaning. The etymology of the word warm comes from Old English warm (adjective) of Germanic origin. The etymology of the temperature term goes "back to Anglo-Saxon times when this Germanic warm was used in its historically primary sense moderately hot" 
(Kleparski, 2007). The second criterion is the dominance in the semantic network which is elaborated in this section. The next one is the relationship between the senses, so it is crucial to show how the temperature term warm is related to other senses. The last feature of a core meaning is that by knowing the sense of the prototypical word, it is possible to predict extended senses.

The concept of warm is having or producing a comfortable and agreeable degree of heat or imparting or maintaining heat. Cambridge defines the word warm as having or producing a comfortable high temperature as shown in these data:

(1) This frog likes a warm, shallow environment, at about $25-25^{\circ} \mathrm{C}\left(77-79^{\circ} \mathrm{F}\right)$

(2) It was a May day just like now, and warm and sunny.

Plank (in Lorenzetti, n.d.) mentions that the temperature terms can described other subdomains, namely: touch, atmospheric, and personal feelings. The data further highlight the three extended senses of the word warm, namely: friendly, pleasant, and near.

\section{Friendly}

The prototypical meaning of the word warm is having a pleasant temperature. This feeling of pleasure is a basic human experience. Consciously or not, the meaning is extended to describe a person's trait or something a person does that gives people pleasure. The sense of the word warm can be found in the natural data taken from the corpus.

(3) There was a humorous light in her keen black eyes that seemed somehow warm and welcoming.

(4) Yet you can be so warm and gentle.

As shown in examples (3) and (4), the word warm tends to be associated with positive feelings of friendliness. Similarly to other temperature descriptors, the term is an extension of the temperature mapping stands for emotions, which is highlighted by Lorenzotti (n.d.) as "alleged to have an experiential basis in the physiological changes". The metaphorical extension is shown through how we experience abstract personality with something more concrete like temperature.

\section{Pleasant to other senses}

The temperature term warm is prototypically considered as an agreeable degree. The sense of the word warm is also extended not only to describe temperature, but also to modify buildings, sounds, and colors, as seen in the data.

(5) The beautiful lady then blushed, a warm and rosy colour in her white cheeks, and was heard to murmur that the spell was as the spell was, that a kiss received after the successful disintegration of the glass casket, was a promise, as kisses are, whether received voluntarily or involuntarily. 
(6) The room was too warm.

(7) We'll be going into a warm house, that's one thing.

(8) The sound is warm and generally well-balanced, though violins are not always

clearly enough defined.

These extended senses of the word warm are motivated by the conceptual metaphor, conceptualizing one domain in terms of another (Pasaribu, 2016). The temperature term warm is something that gives pleasure. We experience this temperature with pleasure. As a 19 result, we can use the adjective warm to describe the feelings towards color (example 5), building (example 6 and example 7), and sounds (example 8).

\section{Near the goal}

In the domain of games, the meaning of warm is near to guessing a correct answer or to discover a hidden object. Oxford Learners' Dictionary elaborate that warm describe "when somebody is warm in a game, he or she has almost guessed the answer to something or that they have almost found somebody/something that has been hidden". The example of this sense can be seen in data (9).

(9) Describing the Hamer's sound is not easy, but if you imagine a normal bass being played through an octaver then you're getting warm.

To see the connection with temperature terms it is urgent to know the senses of lexeme hot. The word hot is also used to indicate - being successful (Pasaribu, 2014). Warm is near to the temperature of hot. This extension makes us possible to say - warm to indicate that a person is almost successful in guessing or finding a hidden object.

The prototype and extended senses of cool

The word cool can be traced back to the Germanic adjective cool (Kleparski, 2007). The primary sense of this word is 'moderately cold'. Compared with other temperature terms, this word is in contrast with the term hot, and it is not that cold to be agreeable. In addition, Kleparski (2007) adds that "the authors of the OED (Oxford English Dictionary) conclude that in earlier use cool was sometimes not distinguished from cold". Cambridge defines the word having a low temperature, but not low enough that it is defined slightly cold in a pleasant way as seen in example (10).

(10) The cool wet climate (Birse, 1971) of the islands affected soil formation in two ways.

It can be highlighted that the prototypical sense of the word cool is having a low temperature, but not as low as the temperature referred by the word cold. The central senses can be extended into several senses found in the data, namely: calm, unfriendly, fashionable, and agreeable. 


\section{Calm}

In contrast with the extended meaning of hot, that is very responsive temperament, one of the extended senses of cool is not heated by passion or emotion. It may refer to a person's ability to stay calm and not become angry or excited.

(11) Comfort can be taken from hoping that her daughter will grow up into a brilliant and glorious human being', but it soon becomes clear that, beneath her cool, confident exterior, Camille too is damaged and vulnerable.

(12) He would say she always did ask too many questions and why didn't she stay cool, tell him she loved him?

It is interesting to note that the temperature word like hot, warm, and cool are used to describe people's emotions or character. When we attribute someone as hot, we consider $\mathrm{him} /$ her responsive in anger toward something unpleasant. When we perceive someone as warm, we consider him/her friendly. Furthermore, by using the adjective cool, we mean that the person given this attribute does not become angry or excited. People use the temperature metaphor to describe character and emotion because the temperature is a very basic human experience.

\section{Unfriendly}

The prototypical meaning of the word warm is the opposite of the word cool. The extended senses of these two words preserving the relationship of the prototypical sense also show opposition. In contrast with the extended meaning of warm 'friendly', the word cool is defined as unfriendly or not being kind or showing interest in something or someone.

(13) She threw him a cool look as she scooped the papers from his desk.

Lorenzetti (n.d.) mentions that "as reported by the Oxford English Dictionary, in its earlier stages, the temperature term cool was frequently employed as a synonym of cold". Both cold and cool indicate the lack of friendliness or warmth. However, the use of the word cold can intensify the behavior. Thus, both in the prototypical and extended senses these words are strongly linked.

\section{Fashionable or attractive}

The word cool is prototypically defined as slightly cold in a pleasant way. In other words, unlike the word cold, it is described positively as agreeable and refreshing. This definition is extended into the domain of appearance. The word cool is also used to describe someone who is fashionable or attractive. The example of this extension can be found below. 
(14) His body is so thick, his skin cool and moist through the thin shirt.

(15) Angie's got some cool new sunglasses.

The positive connotation of the word cool is seen in these examples. We can see through example (14) and (15) that the meaning of the word cool is extended from describing agreeable temperature to modifying people or their features.

\section{Agreeable}

The word cool has a positive connotation as it describes a temperature that is not too cold or a temperature that is agreeable and refreshing. This feature of the word cool can be extended. Therefore, the meaning of the word cool can also be used to say that you agree with something, that you understand it, or that it does not annoy you, as seen in the examples (16).

(16) We all worked and lived at the same place and it seemed pretty cool to me at the time

Example (16) shows the extended sense of the word cool. It is not only used to describe temperature, but it is also used to describe something that is agreeable for the speakers. Many youngsters use this word to indicate that they agree with something or they find it satisfactory.

\section{Discussion}

The findings of the prototype and the extended meaning of the words warm and cool enable us to draw semantic networks that allow users to see the relation among senses. Table (1) highlights the distinct meanings of the prototypical and extended senses of the temperature term warm.

Table 1. Senses of warm

\begin{tabular}{lll}
\hline No. & Senses & Examples \\
\hline 1. & $\begin{array}{l}\text { Warm means 'a } \\
\text { comfortably } \\
\text { high temperature' }\end{array}$ & $\begin{array}{l}\text { This frog likes a warm, shallow environment, at about } 25- \\
25^{\circ} \mathrm{C}\left(77-79^{\circ} \mathrm{F}\right) .\end{array}$ \\
2. & Warm means 'friendly' & $\begin{array}{l}\text { There was a humorous light in her keen black eyes that } \\
\text { seemed somehow warm and welcoming. }\end{array}$ \\
3. & Warm means 'pleasant & $\begin{array}{l}\text { The sound is warm and generally well-balanced, though } \\
\text { violins are not always clearly enough defined. }\end{array}$ \\
t. $\quad \begin{array}{l}\text { Warm means 'near the } \\
\text { goal of the game' }\end{array}$ & $\begin{array}{l}\text { Describing the Hamer's sound is not easy, but if you imagine } \\
\text { a normal bass being played through an octaver then you're } \\
\text { getting warm. }\end{array}$ \\
\hline
\end{tabular}


The semantic network of these senses can be further illustrated in Figure 1:

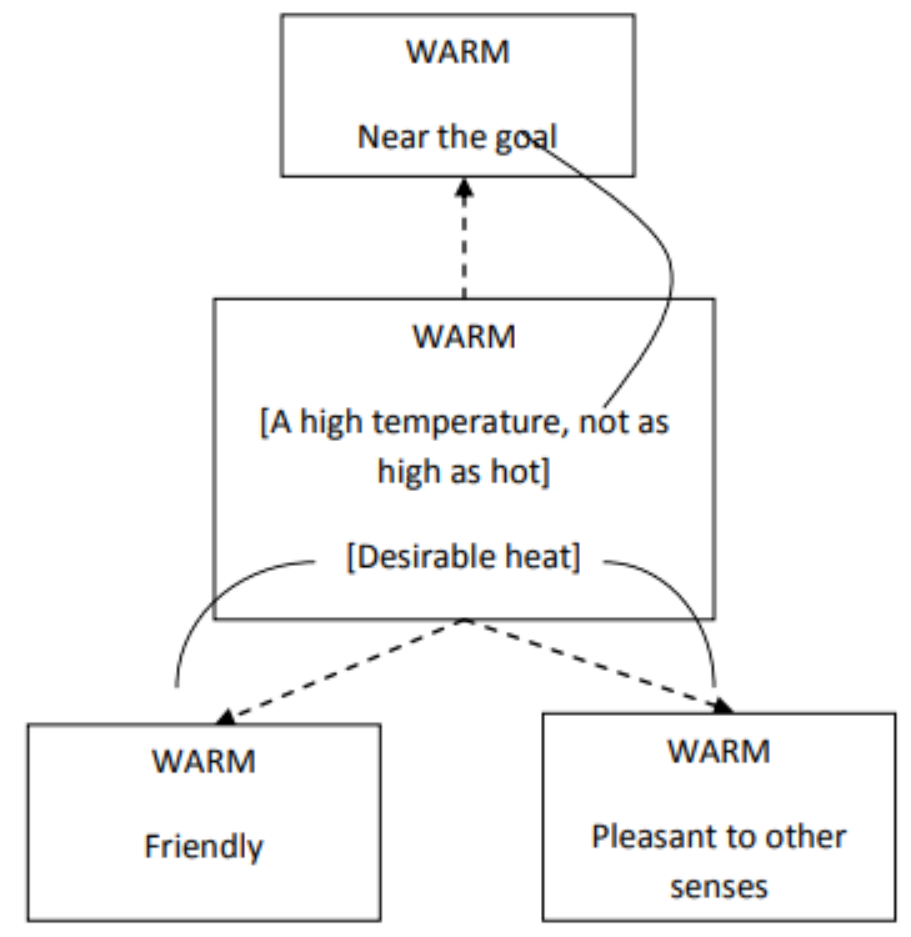

Figure 1. Senses of warm

The senses of the word warm discussed in this research are not as many as those of the word hot (Pasaribu, 2014). One possible explanation for this is that this word does not refer to the highest scale of temperature. Similarly, the word cool also does not refer to the extreme temperature. The word cool whose prototypical meaning is having a low temperature in a pleasant way has four extended senses.

Table 2. Senses of the word cool

\begin{tabular}{|c|c|c|}
\hline No. & Senses & Examples \\
\hline 1. & $\begin{array}{l}\text { Cool means 'a low } \\
\text { temperature in a pleasant way' }\end{array}$ & $\begin{array}{l}\text { The cool wet climate (Birse, 1971) of the islands } \\
\text { affected soil formation in two ways. }\end{array}$ \\
\hline 2. & Cool means 'calm' & $\begin{array}{l}\text { It soon becomes clear that, beneath her cool, confident } \\
\text { exterior, Camille too is damaged and vulnerable. }\end{array}$ \\
\hline 3. & Cool means 'unfriendly' & $\begin{array}{l}\text { She threw him a cool look as she scooped the papers } \\
\text { from his desk. }\end{array}$ \\
\hline 4. & Cool means 'fashionable' & $\begin{array}{l}\text { His body is so thick, his skin cool and moist through } \\
\text { the thin shirt. }\end{array}$ \\
\hline 5. & Cool means 'agreeable' & $\begin{array}{l}\text { We all worked and lived at the same place and it } \\
\text { seemed pretty cool to me at the time. }\end{array}$ \\
\hline
\end{tabular}

Like the word warm, the word semantic network of the prototypical meaning of word cool and its four extended senses can also be represented in Figure 2. 


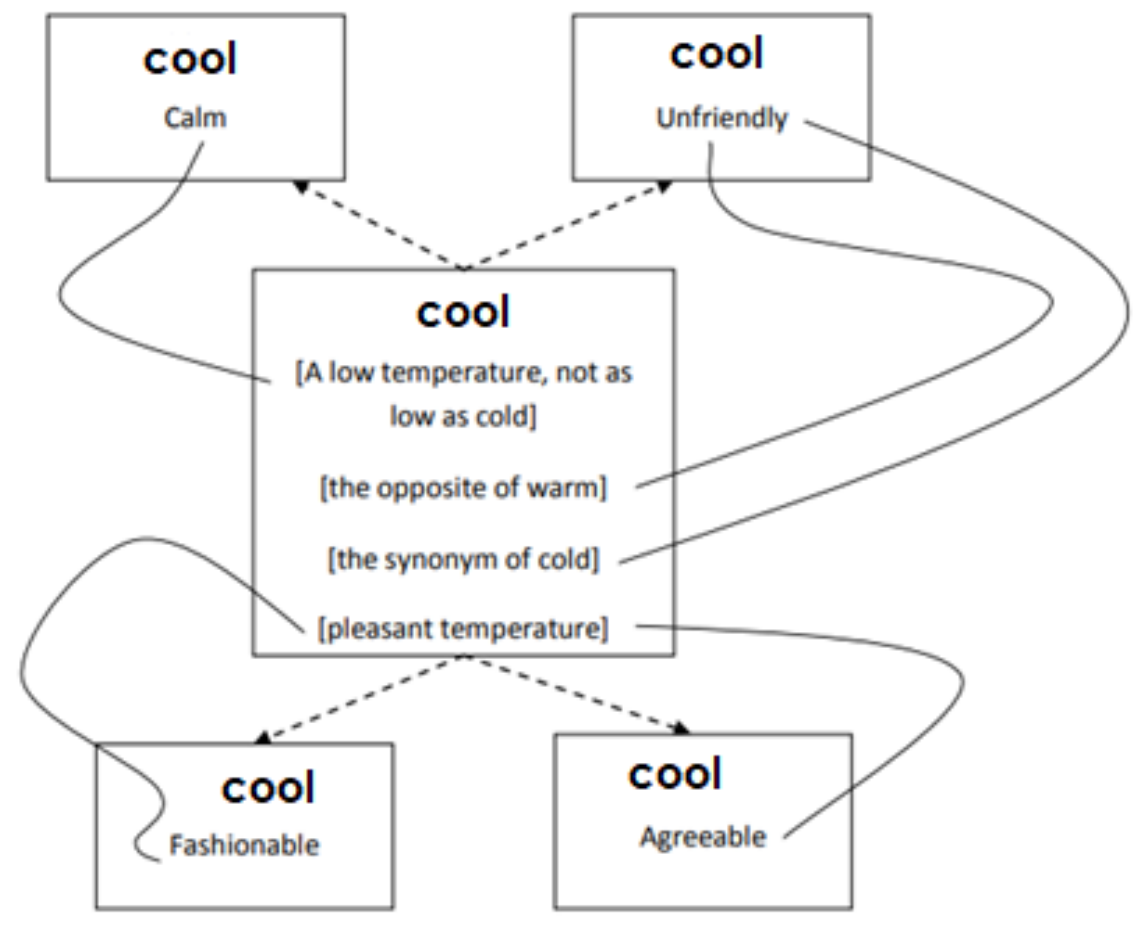

Figure 2. Senses of the word cool

The extension can be traced from their prototypical meaning. The lines highlight how the senses are related to the prototypical one. The extensions of those senses are mostly motivated by metaphors. The domain temperature is pervasive to express non-temperature entities because the temperature is a very basic human experience.

\section{CONCLUSION}

This study has elaborated on the polysemy of temperature terms warm and cool from the framework of Cognitive Linguistics. This framework can be a promising perspective to analyze senses and the relation among them. Users' characteristics, tastes, and possessions can be described by using temperature terms. The study on polysemy can be further elaborated by comparing the extended senses of temperature words in English with other languages. This study has not covered the idiomatic expression of the words in the temperature domain. Thus, future researchers who are interested in the study of idiomatic expression can elaborate on the sense of these words in their idiomatic constructions. Those who are interested in how grammatical construction can expand the meaning of words can elaborate on the word-formation as well as the grammatical construction of these temperature words. In foreign language education, learning polysemy can be a challenge or opportunity to 
improve vocabulary. Further studies on how language learners to study polysemy can be thought-provoking.

\section{BIBLIOGRAPHY}

Ahmad, K. (2000). Neologisms, Nonces and Word Formation. Word Journal Of The International Linguistic Association, II(August), 1-13.

Arcimavičienè, L. (2011). The complex metaphor of political animals in media political discourse: A cross-linguistic perspective. Studies about Languages, 23.

Areshenkoff, C. N., Bub, D. N., \& Masson, M. E. J. (2017). Task-dependent motor representations evoked by spatial words: Implications for embodied accounts of word meaning. Journal of Memory and Language, 92, 158-169. https://doi.org/https://doi.org/10.1016/j.jml.2016.06.006

Birse, E. L. (1971). Assessment of climatic conditions in Scotland (3rd ed.). Aberdeen: Macaulay Institute for Soil Research.

Course, M. (2018). Words beyond meaning in Mapuche language ideology. Language \& Communication, 63, 9-14. https://doi.org/https://doi.org/10.1016/j.langcom.2018.03.007

Cruse, A. (2000). Meaning In Language: An Introduction to Semantics and Pragmatics. Oxford: Oxford University Press.

Deignan, A. (2006). Deignan, A. 2006. "The Grammar of Linguistic Metaphors". Dalam: Stefanowitsch, A. \& Gries, S.Th., penyunting. Corpus-Based Approaches to Metaphor and Metonymy . Berlin: Mouton de Gruyter. p. 106 - 122. In A. Stefanowitsch \& S. Gries (Eds.), Corpus-Based Approaches to Metaphor and Metonymy (p. 106- 122). Berlin: Mouton de Gruyter.

Evans, V., \& Green, M. (2006). Cognitive Linguistics: An Introduction. Edinburgh: Edinburgh University Press.

Falkum, I. L., \& Vicente, A. (2015). Polysemy: Current Perspectives and Approaches. Linguia, (1), 1-39.

Finegan, E., Besnier, N., Blair, D., \& Collins, P. (1992). Language: Its Structure and Use. Sydney: Harcourt Brace Jovanovich.

Hayani, R. (2016). Figurative language on maya angelou selected, 1(2), 131-143.

Ibarretxe-Antuñano, B. (1999). Polysemy and Metaphor in Perception Verbs: A CrossLinguistic Study. University of Edinburgh.

Inčiuraite, L. (2013). Semantic meaning of colours in John Milton's poem paradise lost. Studies about Languages, 23.

Kleparski, G. A. (2007). Hot pants, cold fish and cool customers. Seria Filologiczna.

Lakoff, G., \& Johnson, M. (2003). Metaphors We Live By. Chicago: University of Chicago Press.

Langacker, R. (2008). Cognitive Grammar. Oxford: Oxford University Press.

Linkevičiūte, V. (2013). Conceptual metaphors in gordon brown's political discourse (20072008). Studies about Languages, 23.

Lorenzetti, M. I. (n.d.). " That girl is hot, her dress is so cool, and I' $\mathrm{m}$ just chilling out now ": Emergent metaphorical usages of temperature terms in English and Italian. Unpublished Full Paper, 1-14. 
Maine, F., \& Hofmann, R. (2016). Talking for meaning: The dialogic engagement of teachers and children in a small group reading context. International Journal of Educational Research, 75, 45-56. https://doi.org/https://doi.org/10.1016/j.ijer.2015.10.007

Moreno, A. I. (2005). An Analysis of Cognitive Dimension of Proverbs in English and Spanish: The Conceptual Power of Language Reflecting Popular Believes. SKASE Journal of Theoretical Linguistics, 2(1), 42-54.

Pasaribu, T. A. (2013). Analisis Linguistik Kognitif pada Polisemi Leksem CUT. Universitas Gadjah Mada.

Pasaribu, T. A. (2014). Polysemy and semantic extension of lexeme "Hot." Language and Language Teaching Journal, 17(1), 51-60.

Pasaribu, T. A. (2016). Domains of Political Metaphors in Presidential Speeches. Language and Language Teaching Journal, 19(2).

Pasaribu, Truly Almendo. (2013). Analisis Linguistik Kognitif pada Polisemi Leksem CUT. Universitas Gadjah Mada.

Pasaribu, Truly Almendo. (2014). Polysemy and semantic extension of lexeme "Hot." Language and Language Teaching Journal, 17(1), 51-60.

Šeškauskienè, I., \& Levandauskaitė, T. (2013). Conceptualising Music: Metaphors of Classical Music Reviews. Studies about Languages. https://doi.org/ttps://doi.org/10.5755/j01.sal.0.23.5268

Shalihah, M. (2015). A look at the world through a word "Shoes": A componential analysis of meaning. Journal of Linguistics and Literature, 15(1).

Shalihah, Miftahush. (2015). A Look at the World through a Word "Shoes ": A Componential Analysis of Meaning, 15(1).

Srinivasan, M., Al-Mughairy, S., Foushee, R., \& Barner, D. (2017). Learning language from within: Children use semantic generalizations to infer word meanings. Cognition, 159, 11-24. https://doi.org/https://doi.org/10.1016/j.cognition.2016.10.019

Stasiūnaite, I. (2018). On the Motivated Polysemy of the Lithuanian ŽEMIAU Below. Studies about Languages, 2824(32), 5-20. https://doi.org/10.5755/j01.sal.32.0.19290

Tyler, A., \& Evans, V. (2001). Reconsidering prepositional polysemy networks: The case of over. Language, 77.

Velykoroda, Y. (2019). Conceptual Metaphorization through Precedent-related Phenomena in Media Discourse. Studies about Languages, 34, 32-45.

Wijana, I. D. P. (2012). The use of English in Indonesian adolescent' S SLANG, 24(3), 315323.

Wijaya, G. P. (2011). Polisemi pada Leksem Head: Tinjauan Linguistik Kognitif. Universitas Udayana.

Yasin, A. H., Mustafa, M. A., \& Faysal, T. A. (2010). Neologism a s a Linguistic Phenomenon in Mass Media Textbook w ith Reference to Translation by Abst ra c t T he Conc e pt of $\mathrm{N}$ e ologism.

Yin, Z. (2016). Register-specific meaning categorization of linking adverbials in English. Journal of English for Academic Purposes, 22, 1-18. https://doi.org/https://doi.org/10.1016/j.jeap.2016.01.004 